\title{
Investigating Foreign Language Education through the Lenses of Great Minds
}

\author{
Yang Gao ${ }^{1}$ \\ ${ }^{1}$ School of Teaching, Learning, and Curriculum Studies, Kent State University, OH, the US \\ Correspondence: Yang Gao, School of Teaching, Learning, and Curriculum Studies, Kent State University, OH, \\ the US. Tel: 1-216-534-0688. E-mail: ygao8@kent.edu
}

Received: February 1, 2013 Accepted: February 19, 2013 Online Published: February 22, 2013

doi:10.5539/elt.v6n3p104 URL: http://dx.doi.org/10.5539/elt.v6n3p104

\begin{abstract}
The paper is a brief review of three great philosophers' tenetsand their implications on foreign language education. Based on the recurring themes, namely, Noddings "teaching with care", Dewey's "learning by doing" and Vygotsky's sociocultural theory, the paper highlights the importance of care and love, interaction, practical opportunities and scaffolding in a foreign language classroom, and gives insights on teaching, learning and curriculum design in foreign language education. Leaners in a foreign language classroom may be more struggling with their learning, thus requiring more care and help from their teachers. These philosophies serve as guiding principles to help teachers understand the meaning of their teaching and explore the world of foreign language education.
\end{abstract}

Keywords: education philosophy, foreign language education, care and love, learning by doing, sociocultural theory

\section{Introduction}

Thanks to the winter break, I got the chance to review and re-learn some great philosophies, which shed light on the learning and teaching processes. When I was going through these tenets, I often found them echoed in my personal experiences. Every philosophy has its merits and demerits. As a doctoral student and teacher, Ialso embrace these tenets with a critical thinking, and never take it for granted that there exists a one-size-fit-all philosophy.

I would like to elaborate a few philosophers' tenetsfrom three different perspectives: teaching, learning and curriculum studies (TLC). The reasons for focusing on the three aspects are evident: as a doctoral student from the School of TLC, I need some great wisdom in these aspects to help me better understand and analyze my current and future career; as an English-as-a-foreign-language (EFL) teacher, I also need some guiding principles which may help me explore my research field. It may not be so wise to mark any tenet with a single theme, because some tenets indeed cover more than one perspective; therefore, my illustration on any topic will be integrated with others in some way.

The philosophers who have enlightened me in these aspects are: NelNoddings who raises my awareness of empathy in my teaching; John Dewey, who proposes learning by doingand guides me to rethinkthe learning process; and Lev Vygotsky, whom I am most indebted to,as his sociocultural theoriesshed light on my research emphasis.

\section{Importance of Empathy in Foreign Language Teaching}

My career as a teacher started from 2003, when I began teaching English to Chinese kindergarten students. While it is my first job, it is the most unforgettable experience in my life. Working with the kids was always a big headache not only for me, but also for other teachers, because theywere always naught and active. It was from the working experience that I realized how important that teachersshould show more love, care and empathy to their students. At that time, I had no idea why I should be patient and caring to those kids. It is only when I skimmed the chapters from NelNoddings that I began to find the answers.

A recurring theme in Noddings' works has been careandlove to the students. She holds that the "main aim of education should be to produce competent, caring, loving and lovable people." (Noddings, 2005, p. 8). Similar to other philosophers like John Dewey and Maxine Greene, Noddings agrees that students should master the 
knowledge and skills necessary to help them navigate the world around them. However, besides that, students should simultaneously develop their sense of love and care, and become the loving and lovable persons. The thoughts are embodied in her works on a regular basis, and they shed lights on how teachers should develop their curricula. Noddings (1995) proposes,

"We might consider life stages, spiritual growth, and what it means to develop an admirable character; in exploring the topic of caring for intimate others, we might include units on love, friendship, and parenting; under the theme of caring for strangers and global others, we might study war, poverty, and tolerance; in addressing the human-made world, we might encourage competence with the machines that surround us and a real appreciation for the marvels of technology." (p. 676).

Undoubtedly, the thoughts largely stem from her identity as a mother for ten children, a teacher for millions of students, and a wife for her husband. However, the feminine tenets indeed make sense in helping teachers establish a harmonious and sustainable relationship with their students. This is especially true in an environment of foreign language education, where students have comparatively higher anxiety and reluctance to learn a new language and even a new culture. In order to lower learners' anxiety, teachers should consider more affective factors. We should be more patient and caring, and treat our students like friends and families. In this way, it not only reduces their anxiety in learning but also helps them build stronger self-motivation.

In addition, Noddings also thinks that subjects in school can remain the standard disciplines, but should incorporate more moral themes throughout; she further states "such themes as war, poverty, crime, racism, or sexism can be addressed in almost every subject area." (ibid, p. 676).Noddings holdsthat these themes can be addressed to motivate students' free discussion and thus help them improve not only their academics but also moral and ethical development.Noddings' thoughts have been applied into EFL curriculum design. Textbooks like NorthStar Reading and Writing High Intermediate (second edition) has set up themes of love and care, and moral development in certain units. For example, Unit 2 in the book titles Dreams Never Die, and it selects stories from Helen Keller and other disabled stars. It aims to arouse students' sympathy and encourage them to learn from these heroes.

Noddings' theme on love and care is especially important to learners in the modern world, which is full of competition and aggression. No matter how successful, in terms of his/her material wealth, a person is, he/she must harbor a loving and caring attitude towards others. One who has little love or affection to others would make him/herself indifferent, and his/her world isolated and deserted. Therefore, it is highly suggested textbooks incorporate more themes on care and love into their design, for sake of a caring and loving world.

\section{Effects of Learning by Doing in Foreign Language Classroom}

John Dewey has been influencing scholars all over the world for decades, especially for those who work in the fields of psychology, sociology and education. While Dewey's thoughts in his later years focused more on the education and democracy, it is still his tenet of learning by doing that inspires me most.

Influenced by William James, who is also regarded as one of the three pioneers of American pragmatisms, Dewey proposes that learning is a process of doing and experiencing. Different from James, who is greatly influenced by British empiricism, Dewey prefers naming himself as "instrumentalism", an offspring of British neo-Hegelianism, and attempts to connect idealism and experimentalism. Dewey (1916) perceives knowledge as the tool for managing experience, and states "no such thing as genuine knowledge and fruitful understanding except as the offspring of doing" (p. 322).

The theme of learning by doing permeates all through Dewey's works, and it is especially prominent when he talks about his understanding on learning. In Democracy and Education (1916), Dewey states that one learns in consequence of one's direct activities, and "learning means something which the individual does when he studies" (p. 390).

The theme inspired his following scholars in a multitude of ways. First, his thought that education must engage with and enlarge experience leads scholars to think about the education outside the classroom. Especially in the modern world, competition becomes increasingly fierce, and it coerces people to learn and grasp more and more practical skills. Theoretical knowledge in the classroom sometimes cannot meet people's needs to solve practical problems. Meanwhile, learners also need more practice to digest and understand the theories.

Second, application of learning by doing can also find its trace incertain learning models. With reference to language acquisition, Dell Hymes (1972) proposes that leaners should develop their communicative competence; in turn, Hymes enlightens communicative instruction. The basic tenet of communicative instruction is, in essence, an embodiment of learning by doing. 
Last but not least, Dewey's enthusiasm for democracy, which aims at educating people so that all may share in a common life, also sparkseducators to practice in the associational settings. In Dewey's mind, all institutions are educational in the same way as they all form the attitudes, dispositions, abilities and disabilities that aim for a concrete personality. However, it might take the educators a long way to go, because it involves more factors besides education per se, and factors like ideology, economy and social structure might all set severe barricades on the way to a democratic education.

\section{Influence of Scaffolding in Foreign Language Education}

Lev Vygotsky has been influencing me since I was doing my master study years ago. I heard of his name and tenets for the first timewhen I was taking the course of cognitive linguistics. His philosophy influences more Chinese scholars than other theorists, because he lived in Soviet Union, which had a great connection with China due to geographical or political factors.

In a politically repressive environment always come some great minds, such as Paulo Freire. Similarly, Vygotsky was also living in such a repelling time, when the dictator Joseph Stalin announced the accession to power of brutal communist in 1922. Therefore, most of Vygotsky's scholarly works were not released until 1934, the year when he died of tuberculosis. However, that did not stop people from chasing his thoughts. His developmental psychology in sheer social terms was undoubtedly insightful. To some extent, Vygotsky shares some features in common with John Dewey. Like Dewey who proposes the democratic education, Vygotsky's emphasis on the social plasticity of human beings is an extremely useful addition to the field of developmental psychology.

Far beyond thedevelopmental psychology, Vygotskyan theories also give insights to scholars in the fields like cognitive science, child development and linguistic studies. Especially for child development and cognitive linguistics, most of the basic principles in these fields stemmed from his tenets.

First, Vygotsky (1978) coined the term zone of proximal development (ZPD), and rejected three major theories (constructivism, behaviorism, and gestaltism) at his time. He believed that learning always precedes development in the ZPD, that is, through the assistance of a more capable person (expert), a child (novice) is able to learn skills or aspects of a skill that go beyond the child's actual developmental or maturational level. This is the prototype of scaffolding. In this sense, the ZPD provides a prospective view of cognitive development, as opposed to a retrospective view that characterizes development in terms of a child's independent capabilities.

Second, Vygotsky's contribution also lies in that he inspired scholars like Wertshe, who proposed sociocultural theory. Vygotsky (1987) perceived learning as being embedded within social events, and occurring as a child interacts with people, objects, and events in the environment. He held that learning occurs in interaction rather than through interaction with people. By "in" interaction, Vygotsky emphasized both process and outcome of communication rather than only the outcome. Vygotsky regards language as an external tool to children used insocial interaction. Children are guided their personal behaviors by using this tool in a kind of self-talk, or private speech, which "develops along a rising not a declining, curve; it goes through an evolution, not an involution. In the end, it becomes inner speech" (ibid, p. 57).

Finally, yet importantly, Vygotsky enlightened scholars like Reuven Feuerstein, who proposed the Mediated Learning Experience (MLE). Vygotsky (1978) observed how higher mental functions developed through the interactions and represented the shared knowledge of a culture. This process is known as internalization. The process of internalizations involves different kinds of mediators in the learning process, such as objects (textbooks), others (teachers and peers), and self-regulations (inner speech or private speech). Based on his tenet, MLE is defined as a quality of human-environment interactions, which is "much more than a simple pedagogical model and entails the shaping of cognitive process as a by-product of cultural transmissions" (Feuerstein et al, 1999). All learning interactions can be divided into direct learning and mediated learning. Learning mediated by another human being is indispensable for a child because the mediator helps the child develop prerequisites that then make direct learning effective.

In a nutshell, Vygotsky's philosophy stimulatedscholars and teachers to pay more attention to the importance of scaffolding and mediators. While it is highly recommended to help learners shape their autonomy in such a modern time, it does not entitle teachers to leave their students to fully develop by themselves. It is still teachers' scaffolding that guides students to a more meaningful orientation. In order to achieve learner autonomy (efficient self-regulation), teachers should merit more attention to the role of mediators in students' learning. Questions on how to design a good curriculum and select proper textbooks, and how to pair the students in groups and lead them to peer discussion are all worthy of teachers' consideration and discussion. 


\section{Conclusion}

A reflection paper is always helpful in a number of ways. First of all, the composing process may guide teachers to rethink their teaching philosophy. I used to be misled by the term "learner autonomy", and thought I should let my students freely develop themselves. However, a second look at Vygotsky's tenets made me re-orientate myself. Teachers should play a scaffolding role to students, giving them enough guidance and engaging appropriately in their learning. Shaping their learner autonomy does not mean that teachers are simply the guides keeping an eye open to their students, but also means they are the participants and facilitators in their students' learning. Second, I also find Dewey's tenets echoed in my mind. Creating opportunities that are more practical for students is by all means the most important task for every single teacher. Third, I regard Noddings as my moral guide, who stimulates me to incorporate more care and love into my teaching and learning. The prerequisite for being a qualified teacher is to be a loving and lovable person.

The word of philosophy stems from Latin, and it means love (philo) the wisdom (sophie). Therefore, all philosophies are helpful in leading people to think, analyze and apply the wisdom behind the words; they may also guide people to appreciate and love the wisdom. As a guide, facilitator and friend of our students, we should always ponder on the wisdom of teaching, learning and curriculum studies. Only in this way can we replace an empty mind with an open one, and then inflame our students' minds.

\section{References}

Dewey, J. (1916). Democracy and education. New York, NY: Macmillan.

English, A., \& English, L. M. (2003). NorthStar Reading and Writing High-Intermediate (2nd ed). NJ: Prentice Hall.

Feuerstein, R., Klein, P. S., \& Tannenbaum, A. J. (1999). Mediated Learning Experience (MLE): Theoretical, Psychosocial and Learning Implications. London, UK: Freund Publishing House Ltd.

Hymes, D. (1972). On communicative competence. In J. B. Pride, \& J. Holmes (Eds.), Sociolinguistics: Selected readings (pp. 269-293). Harmondsworth, UK: Penguin Books.

Noddings, N. (1995). Teaching themes of care. Phi Delta Kappan, 76(9), 675-679.

Noddings, N. (2005). The Challenge to Care in Schools: An Alternative Approach to Education (2 ${ }^{\text {nd }}$ d). New York, NY: Teachers College Press.

Vygotsky, L. S. (1978). Mind in Society: The Development of Higher PsychologicalProcesses. Cambridge, MA: Harvard University Press.

Vygotsky, L. S. (1987). The collected works of L. S. Vygotsky: Vol. 1. Problems of general psychology (including the volume Thinking and speech). (N. Minick, trans.). New York: Plenum Press.

Wertsch, J. (1991). Voices of the Mind: A sociocultural approach to mediated action. Cambridge, MA: Harvard University Press.

\section{Author}

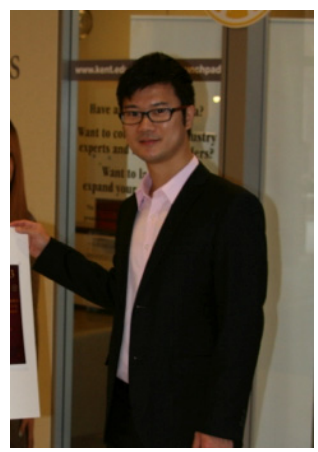

Yang Gao has taught Chinese EFL learners English reading for seven years. He is now the Director of English Department in Worldwide Foreign Languages School, Dalian, China, andalsoa Ph.D. student and graduate assistant in Kent State University, Kent, Ohio. He earned his Bachelor Degree in Applied English from Heilongjiang University, China, and his Master Degree in Applied Linguistics from Dalian Maritime University, China. He also had a TESOL certificate from Kent State University. He used to participate in several national research projects funded by the Department of Education in China. 